\title{
Evolusi Cekungan pada Periode Holosen Kaitannya dengan Fluktuasi Muka Air Laut, Tektonik dan Perubahan Iklim di Nabire dan Sekitarnya, Papua Basin Evolution on Holocen Period Related to the Fluctuation of Sea Level, Tectonic and Climate Change in Nabire and its Surrounding Area, Papua
}

\author{
Rio Alcanadre Tanjung Moechtar \\ Pusat Survei Geologi, Badan Geologi \\ Jl. Diponegoro No.57, Citarum, Bandung Wetan, Kota Bandung, Jawa Barat 40115 \\ email: rioalcanadre@gmail.com) \\ Naskah diterima : 14 November 2019, Revisi terakhir : 19 November 2019 Disetujui : 20 November 2019, Online : 22 November 2019 \\ DOI: http://dx.doi.org/10.33332/jgsm.v20.4.237-248p
}

\begin{abstract}
Abstrak- Daerah penelitian terletak di Kabupaten Nabire, Papua yang sebagian besar wilayahnya ditutupi endapan Kuarter. Penelitian bertujuan untuk mengungkap dinamika Kuarter serta interval proses pengendapan berdasarkan aspek sedimentologi dan stratigrafi. Metode yang dilakukan adalah pemboran dangkal menggunakan hand auger sebanyak 48 titik. Hasil pengeboran menunjukkan 7 (tujuh) fasies pengendapan, yaitu: endapan limpah banjir, endapan cekungan banjir, endapan sungai, endapan rawa bakau, endapan pantai, endapan laut dekat pantai, dan batuan pra-Holosen. Berdasarkan rekonstruksi penampang stratigrafi, kelompok fasies pengendapan tersebut terbagi menjadi dua interval periode pengendapan. Interval periode pengendapan pertama merupakan fasies muka airlaut tinggi (transgresi) dan tersusun atas sistem laut dan sistem rawa. Interval periode pengendapan kedua merupakan fasies muka airlaut rendah (regresi) dan tersusun atas sistem laut, sistem rawa dan sistem sungai. Hasil pentarikhan umur menggunakan metode pentarikhan radiokarbon menunjukkan bahwa batas antara periode pertama dan periode kedua terjadi pada kisaran umur 9.200-10.700 tahun yang lalu. Kemunculan sistem sungai pada periode kedua diakibatkan oleh turunnya muka air laut. Kondisi ini menunjukkan kecenderungan tingkat energi semakin mengecil, berkaitan dengan jumlah volume air ketika itu. Jumlah volume air tersebut berhubungan dengan tingkat kelembapan yang bergantung pada siklus perubahan iklim. Fasies endapan rawa bakau dicirikan dengan keterdapatan Rhizophora sp., Sonneratia alba, dan Bruguiera cylindrica, terjadi penipisan endapan gambut pada fasies tersebut. Peristiwa tersebut menunjukkan bahwa iklim menuju ke kering. Munculnya fasies pantai di bagian tengah fasies endapan rawa bakau membuktikan bahwa ketika muka airlaut turun secara global, secara lokal muka airlaut tinggi pada periode tertentu. Gejala ini cenderung berkaitan dengan turunnya dasar cekungan (base level) akibat tektonik.
\end{abstract}

Katakunci : Muka air laut, tektonik, iklim, Holosen, Nabire

\begin{abstract}
Research area is located in Nabire, Papua, which mostly covered with alluvial deposits. The objective of this research is to delineate the quaternary dynamic by interpreting interval of depositional periode based on sedimentology and stratigraphy aspects. The method used is drilling using hand auger in 10 points. Drilling result shows that there are 48 depositional facies in this area, such as floodplain deposit, floodbasin deposit, channel deposit, mangrove deposit, beach deposit, nearshore deposit and pre-Holocene rocks. Based on stratigraphy reconstructions, the facies group is divided into two interval of depositional periods. First interval is a period when the sea level is high, identical with transgression, and is composed of marine and marsh systems. Second interval is a period when the sea level is low, identical with regression, and is composed of marine, marsh, and fluvial systems. Based on carbon dating analysis, the boundary between first and second interval happened about 9,20010,700 years ago. Fluvial system was found on second period along with the sea level drop and followed by the decrease of the fluvial dimension. This occurence is influenced by energy level reduction that is caused by the diminishment of water volume. Water volume is related to humidity level which indicates the climate change by diminishment of water volume. Water volume is related to humidity level which indicates the climate change. Mangrove deposit, which is marked by Rhizopora sp., Sonneratia alba, and Bruquiea cylindica, experiences peat moss thinning. Those occurences show lead into dry climate in the foreseeable future. Beach sand depositfound in the middle of mangrove deposit proves when sea level drop globally, local sea level rises at specific time in contrast. It is an indication that base level dropping is caused by the effect of tectonic activity.
\end{abstract}

Keywords : Sea level, tectonic, climate, Holocene, Nabire 


\section{PENDAHULUAN}

Indonesia merupakan wilayah dengan kondisi geologi yang rumit dan kompleks sehingga memiliki banyak potensi yang harus dikelola dan dimanfaatkan, baik potensi berupa sumberdaya maupun potensi kebencanaan. Berkaitan dengan hal tersebut maka pemetaan potensi geologi Indonesia harus dilakukan secara integral dan komprehensif dalam rangka peningkatan pengetahuan dan penguasaan data geologi. Penggetahuan dan penguasaan data pada batuan Kuarter juga banyak dikaitkan dengan potensi kebencanaan dan juga menyangkut dinamika geologi yang berkaitan dengan siklus proses pembentukan bumi. Dinamika Kuarter merupakan refleksi yang paling mendekati kondisi saat ini, sehingga dapat digunakan untuk mempelajari maupun memperkirakan proses-proses geologi yang terjadi di permukaan bumi pada masa sekarang. Hal ini sangat berarti dalam upaya pengelolaan dan mitigasi bencana geologi.

Daerah penelitian terletak di Kabupaten Nabire, Papua, yang berada pada koordinat $135^{\circ} 15^{\prime}-135^{\circ} 30^{\prime}$ BT dan $03^{\circ} 15^{\prime}-03^{\circ} 30^{\prime}$ LS . Daerah ini termasuk di dalam lembar peta geologi Enarotali (Harahap dkk.,1990) yang terdukung oleh 4 satuan geologi yaitu Konglomerat Karado (Tpka), Batulumpur Bumi (Tqbm), Anggota Batugamping Legar (Tqle), dan Alluvium (Qa). Sebagian besar wilayah dekat pantai ditutupi endapan Kuarter (Qa) yang tersusun oleh kerikil, pasir, lanau, lumpur karbonat, gambut. Dataran Aluvial (Qa) merupakan hasil interaksi proses laut dan aktifitas aliran sungai (fluvial) selama periode Kuarter, dan dinilai sangat baik untuk studi geologi Kuarter melalui data bawah permukaan (subsurface) geologi khususnya endapan-endapan Kuarter yang belum terekam di penelitian sebelumnya (Bemmelen, 1949). Penelitian itu bertujuan untuk mengungkap data endapan bawah permukaan sehingga dapat diketahui runtunan dan sebaran litofasies, lingkungan pengendapan dan hubungan antar fasies secara vertikal maupun horizontal. Selain itu, dinamika proses dan karakteristik fisik endapan Kuarter dapat dijadikan sebagai acuan sejauh mana pengaruh tektonik, iklim dan fluktuasi muka air laut.

Kontrol dinamika proses sedimentasi dapat dikenali berdasarkan perubahan kondisi muka airlaut, tektonik, iklim dan evolusi biotik (Walker dan James, 1992). Perubahan yang terjadi akan mempengaruhi mekanisme dan proses pengendapan dari komplek endapan fluvial yang dibedakan menjadi autogenik (proses internal) dan allogenik (proses eksternal) (Allen dan Allen, 1990). Endapan aluvial-fluvial merupakan komponen penting dalam stratigrafi untuk merekonstruksi kondisi tektonik yang memiliki sebaran yang luas (Miall, 1992).

Tebalnya batuan sedimen pada cekungan Tersier yang mencapai $3.000 \mathrm{~m}$ terjadi dikarenakan adanya penurunan yang aktif hingga kini, dengan laju penurunan dasar cekungan lebih besar dari laju sedimentasi (Bachri, 2014). Oleh karena itu, penting untuk mengetahui sampai sejauh mana efek tektonik mempengaruhi endapan-endapan Kuarter. Selain itu, aspek-aspek sedimentologi dan stratigrafi yang dihasilkan dalam penjabaran dataran aluvial di Nabire merupakan informasi penting yang dapat dijadikan acuan dalam dinamika Kuarter yang meliputi 3 aspek, yaitu fluktuasi muka air laut, tektonik, dan perubahan iklim. Sejarah pembentukan cekungan pada periode Kuarter dapat direkonstruksi berdasarkan posisi stratigrafi endapan secara tegak dan horizontal serta dari perubahan lingkungan pengendapannya.

\section{METODOLOGI}

Pengambil sampel endapan aluvial dengan pemboran dangkal (hand auger) di 48 titik bor pada wilayah dataran aluvial. Kedalaman pemboran berkisar 0,6 $12,3 \mathrm{~m}$ dan kedalaman rata-rata 5,3 $\mathrm{m}$. Endapan yang diperoleh melalui hasil pemboran kemudian dideskripsi sifat fisik, warna, kandungan fosil, kandungan mineral, besar butir, bentuk butir, ketebalan lapisan serta aspek fisik lainnya. Selain itu juga diuraikan jenis dan fasies lingkungan pengendapannya

Berdasarkan hasil deskripsi tersebut, setiap titik bor dikorelasikan dan ditafsirkan hubungan masing-masing fasies pengendapannya baik secara vertikal maupun horizontal, analisis proses sedimentasi dan dinamika proses pengendapan yang terjadi pada dataran aluvial tersebut. Dalam analisis tersebut dapat dirangkai menjadi beberapa interval susunan pengendapan yang dapat dibedakan antara satu dengan yang lainnya atau bisa disebut juga interval proses pengendapan. Dari rangkaian susunan interval tersebut, faktor kendali proses pengendapan khususnya pengaruh naik turunnya muka airlaut, tektonik dan sirkulasi iklim. Selain pengukuran di lapangan, penelitian ini juga dibantu dengan analisis laboratorium berupa analisis pentarikhan radiokarbon untuk umur mutlak dan palinologi untuk menentukan lingkungan pengendapannya pada beberapa sampel endapan rawa, endapan limpah banjir dan juga endapan laut dekat pantai digunakan untuk menguatkan analisis 
sedimentologi dan stratigrafi. Hasil uji analisis palinologi merupakan pembahasan sendiri sehingga tidak disinggung dalam tulisan ini.

\section{FISIOGRAFI DAN GEOLOGI}

Secara regional daerah penelitian terbagi menjadi empat satuan fisiografi, yaitu dataran pantai pesisir dan rawa, dataran aluvium terbiku (tertoreh), perbukitan berlereng landai dengan lembah terbuka dan pelataran batugamping. Berdasarkan peta geologi Lembar Enarotali, Irian Jaya Skala 1 : 250.000 (Harahap dkk., 1990) daerah penelitian termasuk ke dalam morfologi bentang alam dataran dan perbukitan berlereng landai. Pada morfologi yang demikian ini biasanya berkembang pola alir subdendritik hingga dendritik. Pola alir yang demikian ini bisa berkembang oleh karena komposisi litologi yang berbutir halus dan homogen serta bentuk morfologi yang datar.

Daerah penelitian berada di pangkal Teluk Cendrawasih. Morfologi dataran dibatasi oleh pegunungan di sebelah selatan dengan Elevasi berkisar antara 0-300 $\mathrm{m}$ di atas permukaan laut (mdpl). Kawasan perbukitan di bagian selatan merupakan bukit-bukit bergelombang yang disusun oleh batuan lunak batulumpur dan perbukitan batukapur di bagian tenggaranya. Terdapat 4 sungai utama yang bermuara ke Teluk Cendrawasih, dari timur ke barat, yaitu Sungai Nabire, Sungai Bumi, Sungai Wanggar dan Sungai Yaro.

Sungai Nabire di bagian timur daerah penelitian menjadi batas antara Distrik Nabire dengan Distrik Nabire Barat. Sungai Bumi merupakan sungai yang cukup besar dan di bagian tenggara, tepatnya di kawasan perbukitan Kapur Uwapa, sungai ini mengalir lurus melewati lembah terjal. Keluar dari lembah terjal, alirannya membentuk meander dengan dataran banjir yang cukup luas (Gambar 1). Pada meander-meander ini teramati juga bentukan-bentukan danau tapal kuda dan gosong tepi. Di bagian muaranya, teramati bentukan delta yang maju. Dugaannya adalah pasokan sedimen dari hulu cenderung banyak dan pengaruh gelombang yang relatif kurang atau bersifat delta dengan pengaruh sungai.

Sungai Wanggar dan Sungai Yaro bermuara ke Teluk Yaro. Berbeda dengan Sungai Bumi yang deltanya relatif maju ke arah laut, muara Sungai Wanggar dan Sungai Yaro berada di Teluk Wanggar dan tidak membentuk delta. Kejadian ini diduga karena pasokan sedimen yang cenderung sedikit atau terdapat proses lain yang membentuknya seperti pengangkatan. Kedua sungai ini berimpit terutama di sekitar daerah Yaro hingga muaranya di Teluk Wanggar.

Kabupaten Nabire berkembang cukup pesat. Sudah banyak pemukiman-pemukiman. Berdasarkan peta topografi lembar Nabire, pemukiman-pemukiman umumnya berada pada elevasi 0-15 mdpl. Kota Nabire, Kelurahan Bumi Wonorejo dan Kelurahan Kalibobo berkembang di daerah dataran banjir dan pesisir pantai Sungai Nabire. Kelurahan Nabire Barat, Wadio, Kalisemen, dan Bumiraya berkembang di dataran banjir Sungai Bumi sebelah timur, sementara Bumimulia berkembang di dataran banjir Sungai Bumi sebelah barat. Batas kelurahan terutama daerah tinggian, baik tinggian batugamping dan tinggian batulumpur.

Daerah Wiraska dan Yaro berkembang di daerah dataran banjir Sungai Yaro dan Sungai Wanggar. Di bagian barat daerah penelitian terdapat Sungai Ayar dengan dataran yang diduga berupa lahan rawa gambut.

Bentukan geomorfologi daerah penelitian seperti yang dimodelkan pada buku Tools to fluvial geomorphology oleh Kondolf dan Piegay (2016; Gambar 2) dapat diamati bahwa daerah pegunungan berada di bagian selatan, yang kemudian berbatasan langsung dengan dataran Sungai Bumi di bagian utaranya. Dataran ini menerus hingga ke pantai. Perbedaan dengan gambar di bawah ini yaitu di daerah Nabire tidak berkembang estuarin, sedimen ke pantai cenderung sedikit dan pantai cenderung jernih. Hal ini cukup menarik dalam konteks geologi Kuarter.

Berdasarkan Peta Geologi Lembar Enarotali, Irian Jaya Skala 1 : 250.000 (Harahap dkk., 1990; Gambar 3), daerah penelitian disusun oleh Endapan Aluvium (Qa), Batulumpur Bumi (TQbm), Anggota Batugamping Legare (TQle), Konglomerat Karado (Tpka). Endapan Aluvium (Qa) terdiri atas kerikil, pasir, lanau, lumpur karbonat, gambut. Batulumpur Bumi (TQbm) terdiri atas batulumpur pasiran dan lanauan dengan perselingan batunapal, batupasir dan batulanau, biasanya karbonan; setempat lensa tebal dari konglomerat dan lapisan koquina. Anggota Batugamping Legare (TQle) disusun oleh biokalkarenit, kalsidurit dan mikrit setempat, biasanya sarang atau guaan. Konglomerat Karado (Tpka) berupa konglomerat polimik, sedikit batupasir berkerakal, batulumpur, dan lapisan dan lensa tuf. 


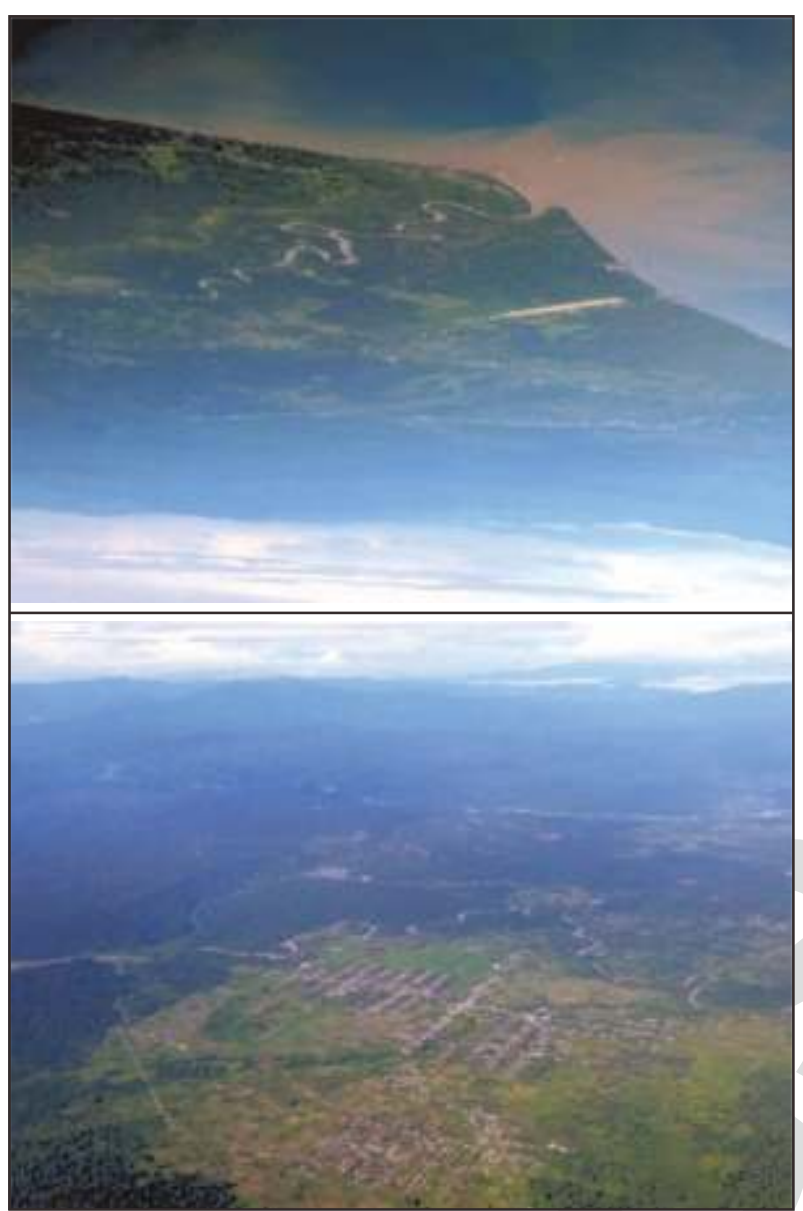

Gambar 1. Sungai Bumi dari udara (gambar atas) dan dataran Bumiraya yang berada tepat di depan perbukitan batugamping di selatannya membentuk dataran banjir yang luas dan subur dimanfaatkan sebagai kawasan transmigrasi.

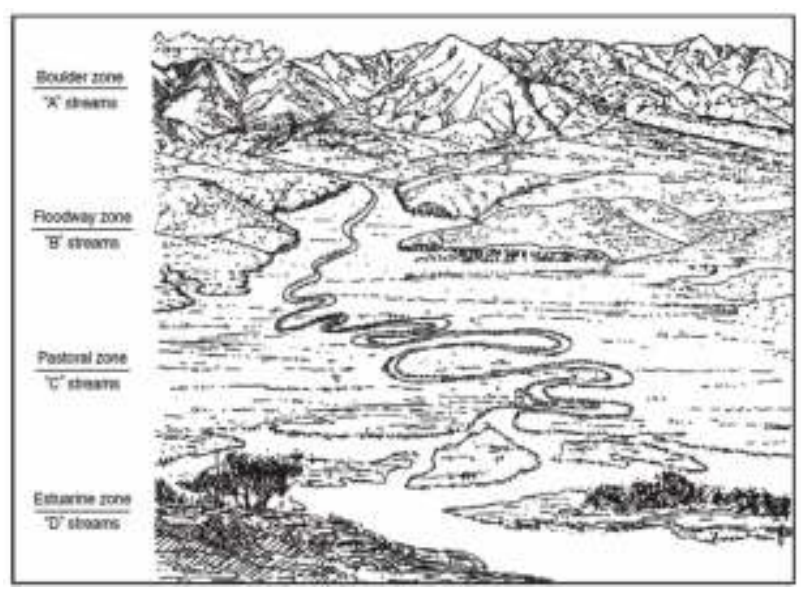

Gambar 2. Sistem ideal sungai dari daerah pegunungan, area sungai bermeander dan delta sungai, yang teramati dengan baik di Nabire (Kondolf dan Piegay, 2016).

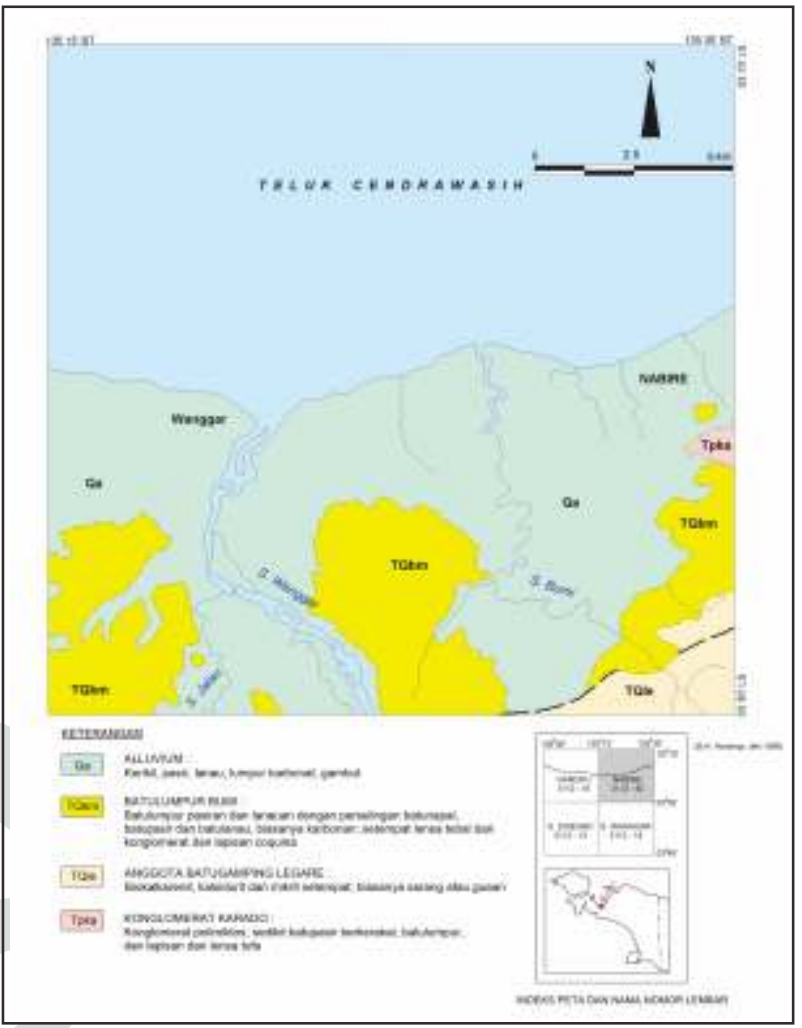

Gambar 3. Peta Geologi Lembar Enarotal Irian Jaya (Harahap dkk., 1990).

\section{HASIL DAN PEMBAHASAN}

\section{Sedimentologi}

Berdasarkan hasil pengeboran sebanyak 48 titik pengeboran terdapat 6 fasies lingkungan pengendanpan dan 1 (satu) batuan pra-Holosen yang kemudian dikorelasikan ke dalam 5 rangkaian stratigrafi (Gambar 4). Keenam fasies pengendapan tersebut, yaitu endapan limpah banjir, endapan cekungan banjir, endapan rawa, endapan pantai, endapan alur sungai, dan endapan laut dekat pantai (Gambar 5).

\section{Endapan Limpah Banjir}

Endapan limpah banjir terdapat di bagian atas yang menutupi endapan-endapan Kuarter lainnya, tersusun oleh lempung, lanau, lempung lanauan dan terdapat sedikit sisipan pasir halus berwarna abu-abu muda hingga abu-abu kecoklatan. Endapan ini biasanya terdapat bercak-bercak berwarna kuning hingga kemerahan yang diwarnai oleh tingkat kandungan humus dan konkresi besi. Endapan ini bersifat pejal, padat, dan sulit untuk ditembus mata bor dengan tingkat kekenyalan yang tinggi dan terdapat sisa-sisa tumbuhan yang tidak dominan sebarannya. 


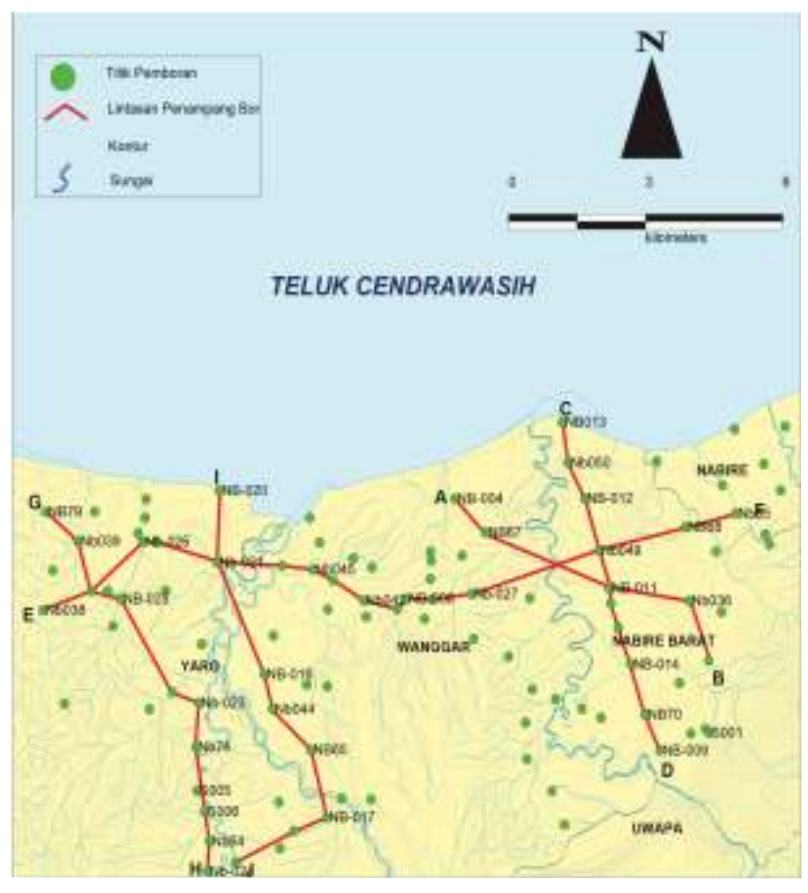

Gambar 4. Korelasi titik pengeboran sebanyak 5 rangkaian pada daerah penelitian.

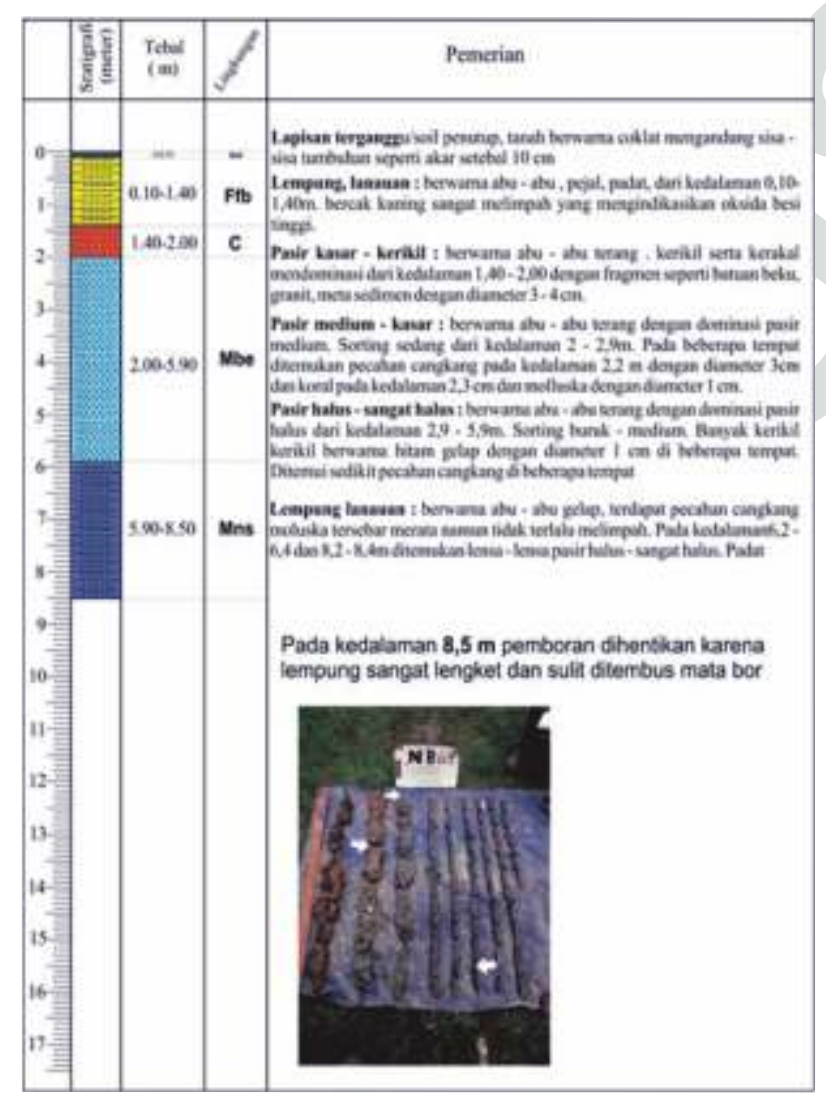

Gambar 5. Contoh log deskripsi hasil pemboran dangkal.

\section{Endapan Cekungan Banjir}

Endapan cekungan banjir umumnya didominasi oleh lempung lanauan dan lempung pasiran berwarna abuabu kecoklatan hingga abu-abu kemerahan dan dijumpai konkresi kecil berupa mangan di beberapa tempat dan bersifat pejal, plastis, padat.

\section{Endapan Rawa}

Endapan rawa umumnya didominasi oleh gambut berwarna coklat tua kemerahan dan gambut lempungan hingga lempung gambutan dengan warna abu-abu tua kehijauan dan mengandung banyak humus tersebar merata berwarna coklat muda. Endapan ini pada umumnya bersifat agak padat, mudah patah, dan lembab dan terdapat banyak material organik serperti sisa tanaman berupa daun, ranting serta batang kayu.

\section{Endapan Pantai}

Endapan pantai mempunyai karakteristik pasir berbutir halus hingga menengah berwarna abu-abu muda hingga abu-abu kehijauan, pemilahan sedang, dan kadang dijumpai pecahan halus moluska dan material organik sisa tumbuhan. Semakin di bawah interval, endapan pasir ini memperlihatkan warna yang semakin gelap berupa pasir berwarna abu-abu kehijauan dan miskin kandungan organik.

\section{Endapan Alur Sungai}

Endapan alur sungai mempunyai karakteristik pasir sedang hingga sangat kasar, bahkan mencapai ukuran butir kerikil dan kerakal dengan bentuk membulat tanggung dengan diameter $1-3 \mathrm{~cm}$, berwarna abu-abu terang hingga abu-abu gelap. Setempat terdapat gravel dengan komponen terdiri dari sedimen, meta sedimen hingga batuan beku, kuarsa serta mika. Pasir ini bersifat urai dengan pemilahan yang buruk. Perubahan butir yang menghalus ke arah atas menjadi karakter susunan butirnya (fining upwards sequence).

\section{Endapan Laut Dekat Pantai}

Endapan laut dekat pantai umumnya ditandai oleh lanau kadang lempung pasiran serta terdapat lensalensa atau kantong pasir halus dan banyak mengandung moluska, warna dari endapan ini adalah abu-abu muda hingga abu-abu gelap dan dijumpai sisipan tipis pasir halus yang mengandung sisa-sisa tumbuhan dan material organik lainnya. 


\section{Batuan pra-Holosen}

Batuan pra-Holosen berupa batuan beku andesit yang merupakan komponen dari konglomerat pada Formasi Batulumpur Bumi.

\section{Stratigrafi}

Sejumlah lima korelasi titik pengeboran dilakukan untuk mengetahui komposisi rangkaian pengendapannya. Pada korelasi tersebut terdapat dua periode interval proses pengendapan, yaitu ketika periode muka air laut tinggi atau transgresi (IPP I) dan juga periode ketika muka air laut rendah atau regresi (IPPII). Lebih lanjut dapat diuraikan sebagai berikut:

\section{Rangkaian Stratigrafi A-B}

Seperti yang terlihat pada Gambar 6, IPP 1 ditandai dengan muka airlaut tinggi dan terbentuk fasies laut dekat pantai di sebelah timur Kabupaten Nabire. IPP 2 dicirikan oleh muka airlaut rendah atau mengalami regresi. Awal proses pengendapan berupa lingkungan rawa bakau di daerah Kalibobo dan ditafsirkan sebagai kecepatan muka airlaut turun relatif cepat ketika itu, sehingga kecepatan sedimentasi (sedimentation rate) menjadi lebih kecil. Di atas fasies rawa bakau diendapkan fasies laut dekat pantai, muka airlaut kembali naik dan selanjutnya ditutupi oleh fasies dataran banjir. Proses ini memberi indikasi bahwa muka airlaut kembali turun. Kondisi demikian dapat dinyatakan bahwa kecepatan muka airlaut relatif cepat karena tidak terbentuknya fasies pantai Di daerah Wanggar berkembang fasies pantai yang seumur dengan fasies pantai di daerah Kalisemen.

\section{Interpretasi}

Efek turun naiknya dasar cekungan terlihat penampang ini mengindikasikan terjadinya tektonik pada daerah ini. Ketika muka airlaut tinggi di daerah ini terjadi pengangkatan ditandai dengan terbentuknya fasies rawa di daerah Kalisemen. Base level kembali turun di daerah tersebut yang menyebakan terbentuknya fasies laut dekat pantai dan selanjutnya muka airlaut kembali turun mengikuti periode regresi secara regional. Turun naiknya muka airlaut tergantung kecepatan naik dan turunnya base level, sehingga selama regresi posisi garis pantai berubah. Hal ini menunjukkan bahwa efek tektonik berpengaruh pada daerah tersebut. Perbedaan elevasi di Kalisemen merupakan salah satu efek pengangkatan base level sehingga posisinya lebih tinggi dibanding daerah Karadiri.

\section{Rangkaian Stratigrafi C-D}

Rangkaian stratigrafi pada Gambar 7, IPP 1 ditandai dengan garis pantai yg tersusun oleh fasies pantai di daerah Kalibumi berbatasan dengan fasies laut dekat pantai di daerah Bumimulia hingga Waroki yang menutupi batuan pra-Holosen. IPP 2 terendapkan fasies pantai di daerah Waroki dengan fasies cekungan banjir di daerah Kalibumi. Di daerah Bumimulia terendapkan fasies dataran banjir yang menjemari dengan fasies pantai yang merupakan daerah pasang surut dan seumur dengan fasies cekungan banjir.

\section{Interpretasi}

Daerah tersebut merupakan daerah yang paling stabil dibandingkan daerah yang lain karena tidak terekamnya efek tektonik. Di Kalibumi tidak dijumpai fasies fluvial sehingga patut diduga alur sungai tidak berkembang di daerah tersebut. Berkembangnya fasies pantai di Kalibumi kemungkinan karena dasar cekungan yang relatif landai.

\section{Rangkaian Stratigrafi E-F}

Seperti yang tampak pada Gambar 8, periode IPP 1 fasies nearshore mengisi bagian terendah dari morfologi batuan alas pra-Holosen. Pada daerah Kalisemen sebelah timur lokasi penelitian, puncak muka airlaut ditandai oleh terbentuknya fasies pantai yang menjemari dengan fasies fluvial, terutama endapan limpah banjir. Pada periode regresi, di daerah Yaro, sebelah barat lokasi penelitian, fasies rawa bakau ditutupi oleh fasies fluvial dan pantai, sedangkan di daerah Kaladiri, berkembang fasies pantai yang ditutupi oleh fasies rawa dan endapan limpah banjir. Di daerah Kalisemen terbentuk fasies pantai, yang kemudian menyusut diiringi dengan terbentuknya rawa sekarang.

\section{Interpretasi}

Cekungan Kuarter ini awalnya terbentuk di antara ketinggian batuan dasar pra-Holosen, kemudian daerah Yaro beralih turun membentuk cekungan. Bagian terendah poros cekungan pada awalnya terletak di daerah Kalisemen sehingga endapan pantai dapat terendapkan di wilayah tersebut. Proses terbentuknya lingkungan rawa berasal dari turunnya daerah tersebut yang merupakan daerah genangan dan menyebabkan fasies rawa dapat terbentuk, sedangkan di daerah Kalisemen elevasi menjadi tinggi hingga sekarang. Pada awalnya daerah Yaro terjadi penurunan muka airlaut secara cepat karena endapan pantai yang tidak terbentuk melainkan terbentuknya rawa. Efek turun naiknya base level sangat mempengaruhi daerah ini, dan penampang yang ada dapat dikorelasikan dengan Penampang A-B. 


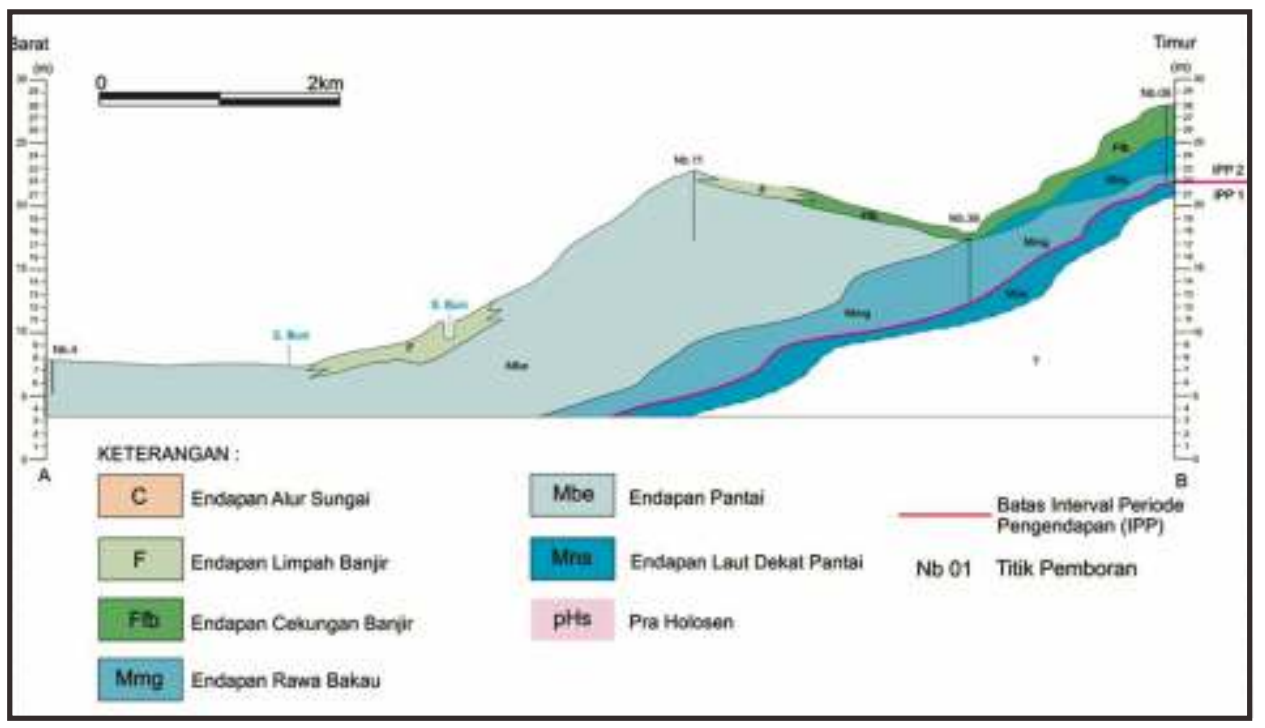

Gambar 6. Rangkaian stratigrafi penampang A-B.

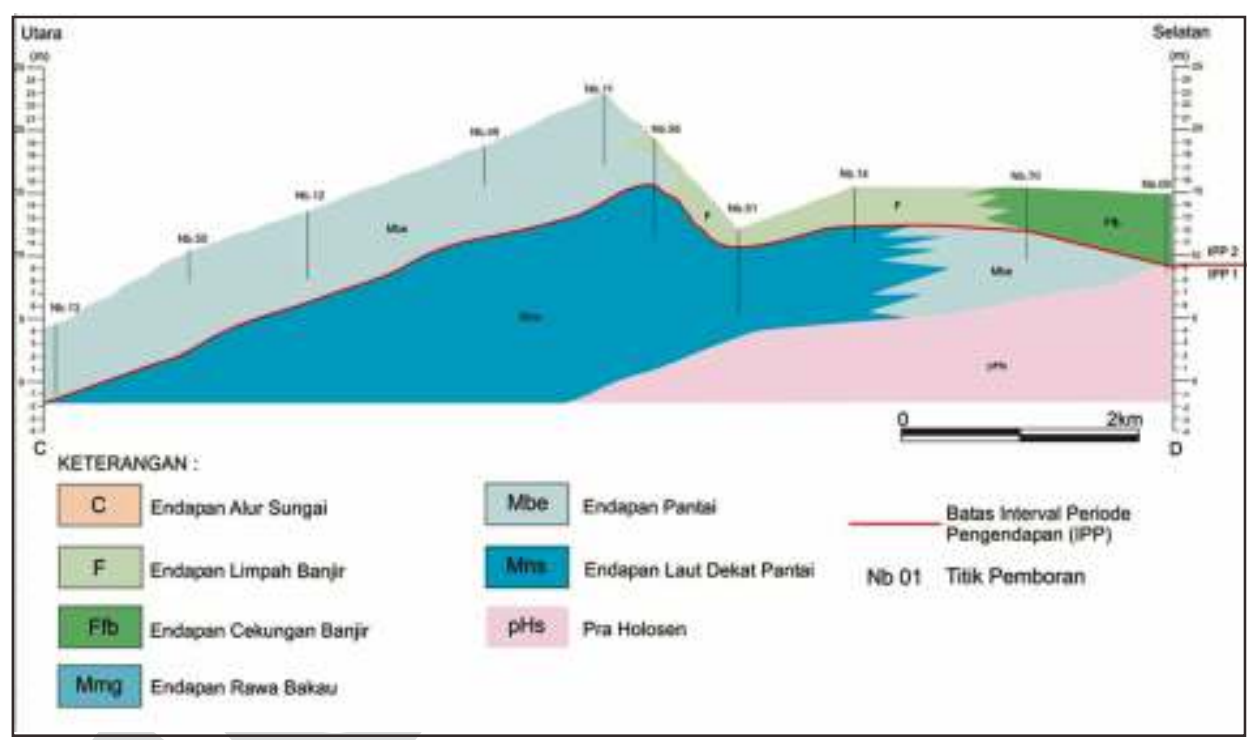

Gambar 7. Rangkaian stratigrafi penampang C-D.

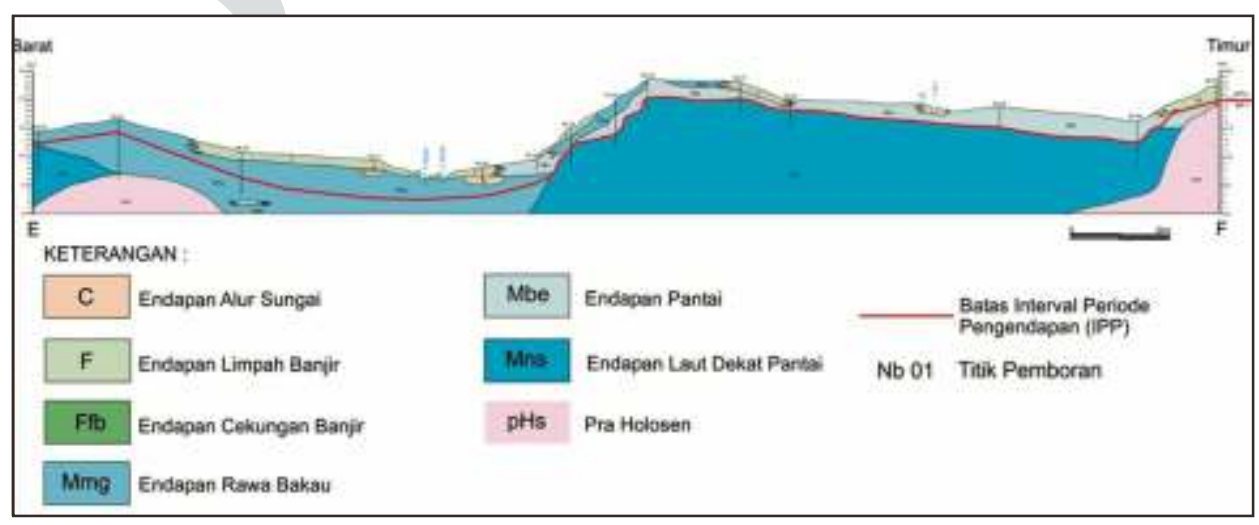

Gambar 8. Rangkaian stratigrafi penampang E-F. 


\section{Rangkaian Stratigrafi G-H}

Seperti yang terlihat pada Gambar 9, IPP I ditandai oleh fasies laut dan rawa bakau yg menutupi pra-Holosen. Batas interval I ini ditandai oleh naiknya muka airlaut tanpa diendapkannya fasies pantai. Hal ini bisa saja terjadi karena morfologi batuan alas pra-holosen relatif terjal. Terbentuknya rawa bakau di atas pra-Holosen tentunya ditunjang oleh volume air yang memadai saat itu. Selain itu, fasies rawa tersebut ditandai dengan terbentuknya lapisan gambut dan batang kayu di dalamnya yang berwarna gelap, sedangkan semakin ke arah atas warna lapisan semakin terang, abu-abu hingga kecoklatan. IPP II ditandai dengan berkembangnya fasies pantai, sebaliknya di daerah Yaro Makmur berkembang fasies rawa, dan fluviatil di Jayamukti. Fasies pantai berasosiasi dengan fasies rawa di daerah Yaro selanjutnya ditutupi oleh fasies cekungan banjir dan dataran banjir, membuktikan bahwa lingkungan rawa menyusut dan alur sungai berkembang hingga ke pantai.

\section{Interpretasi}

Di daerah Jayamukti fasies rawa disisipi oleh fasies pantai ini mengindikasikan bahwa pada periode waktu tertentu muka airlaut naik, atau dengan kata lain bahwa ada pengaruh tektonik. Fasies pantai yang terbentuk membuktikan garis pantai di wilayah ini tidak lurus atau mengindikasikan wilayah ini dahulunya berbentuk teluk. Selama periode pengendapan ini, sistem fluvial sangat dominan terbentuk di selatan yang ditutupi di bagian atasnya oleh fasies limpah banjir sebagai indikasi bahwa alur sungai mengalami perpindahan. Fasies rawa ditandai dengan perubahan warna yang semakin gelap sebagai indikator batas antara IPP I dan IPP II setara dengan dengan puncak muka airlaut tinggi dimana lingkungan rawa bakau berkembang.

\section{Rangkaian Stratigrafi I-J}

Di rangkaian stratigrafi yang terlihat pada Gambar 10 tidak ditemukan IPP I dari proses pengendapan ketika puncak muka air laut tinggi. Hal ini disebabkan karena di tempat tersebut terhalang oleh batuan pra-Holosen yang elevasinya cukup tinggi. Kemungkinan interval periode 1 terbentuk di bagian utara yang dicirikan nearshore, hanya saja tidak ditemukan bukti dari pengeboran. Interval periode 2 yang seiring regresi dicirikan oleh bentuk permukaan morfologi fasies praHolosen yang tidak homogen. Di atas pra-Holosen diendapkan fasies fluvial dan cekungan banjir mulai dari sungai Wanggar hingga ke arah selatan dan tidak dijumpai fasies laut dan pantai. Didasari komposisi fasies tersebut, dapat ditafsirkan bahwa muka airlaut tidak pernah sampai ke tempat tersebut. Di utara ditemukan fasies pantai yang berintegrasi dengan fasies fluvial sehingga diinterpretasikan kedua fasies tersebut dapat dikorelasikan seumur.

\section{Interpretasi}

Ketika IPP I tidak terbentuk fasies laut dekat pantai dan pantai di daerah Yaromakmur membuktikan bahwa elevasinya lebih tinggi yang ditutupi oleh pra-Holosen mengindikasikan daerah tersebut mengalami pengangkatan sehingga muka air laut tidak sampai pada periode tersebut. Terbentuknya fasies dataran banjir yang menutupi alur sungai di Yaromakmur membuktikan bahwa sungai mengalami perpindahan. Fasies cekungan banjir yang terbentuk sepanjang rangkaian adalah akibat menyusutnya fasies fluvial sehingga material-material pra-Holosen mensuplai material ke cekungan tersebut. Pada daerah Yaro tidak menutup kemungkinan merupakan bagian terendah wilayah ini sehingga fasies laut dan pantai tidak dapat terbentuk di bagian bawah.

\section{PEMBAHASAN DAN DISKUSI}

Berdasarkan lima rangkaian stratigrafi di atas, maka secara keseluruhan interval periode pengendapan pertama merupakan periode ketika muka air laut naik atau transgresi, terbentuk sistem rawa dan sistem laut, yang terdiri atas endapan laut dekat pantai, endapan pantai, dan endapan rawa (Gambar 11). Pada sistem laut interval periode pertama, fasies pantai terbentuk bersamaan dengan fasies laut dekat pantai dan sistem rawa hanya terdapat fasies rawa.

Pada interval periode pengendapan kedua merupakan periode ketika muka air laut turun atau regresi, terbentuk tiga sistem, yaitu sistem rawa, sungai dan laut, yang terdiri atas endapan rawa, endapan limpah banjir, endapan cekungan banjir, endapan alur sungai, endapan pantai, dan endapan laut dekat pantai. Sistem rawa pada interval kedua ini merupakan fasies rawa yang ditutupi fasies limpah banjir yang menjemari dengan fasies cekungan banjir. Sistem sungai yang pada interval periode pengendapan kedua ini dibentuk oleh fasies alur sungai yang ditutupi oleh fasies limpah banjir dan fasies cekungan banjir. Sistem terakhir pada periode ini yang terbentuk adalah sistem laut yang dibentuk oleh fasies laut dekat pantai yang pembentukannya seumur dengan fasies pantai dan fasies rawa. 


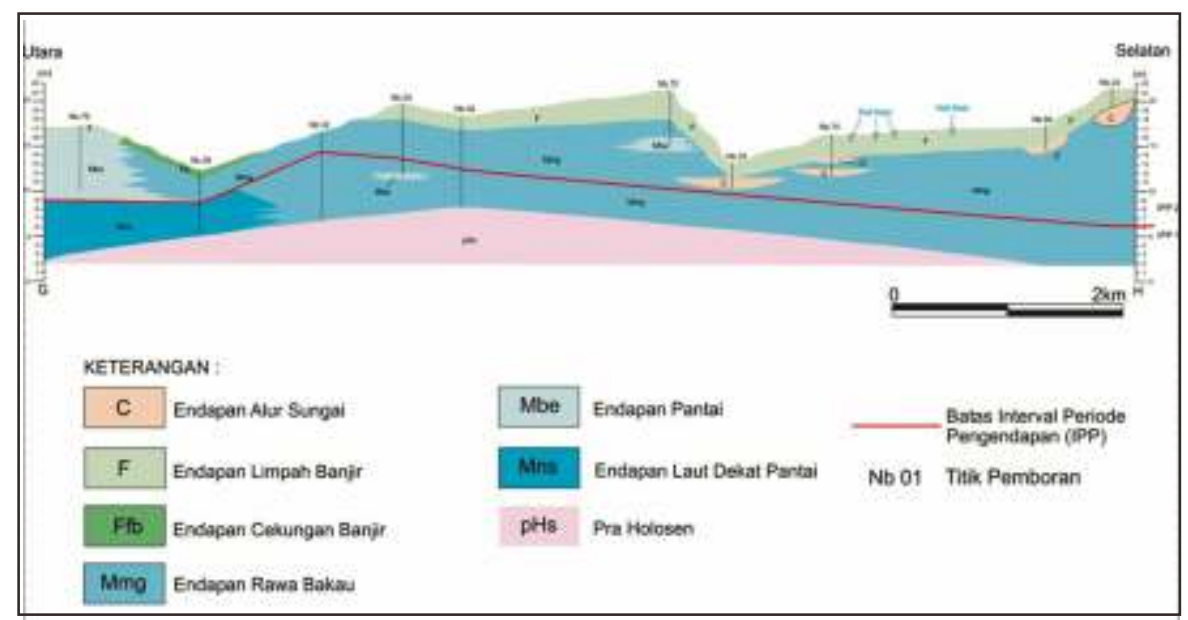

Gambar 9. Rangkaian Stratigrafi Penampang G-H

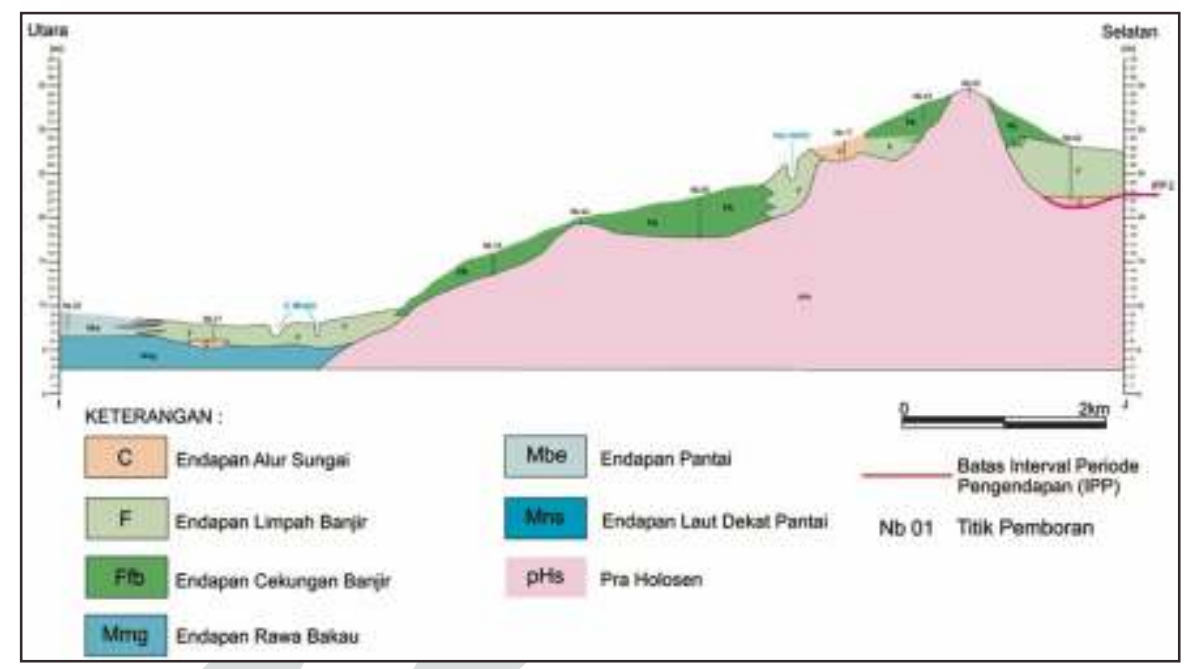

Gambar 10. Rangkaian stratigrafi penampang I-J.

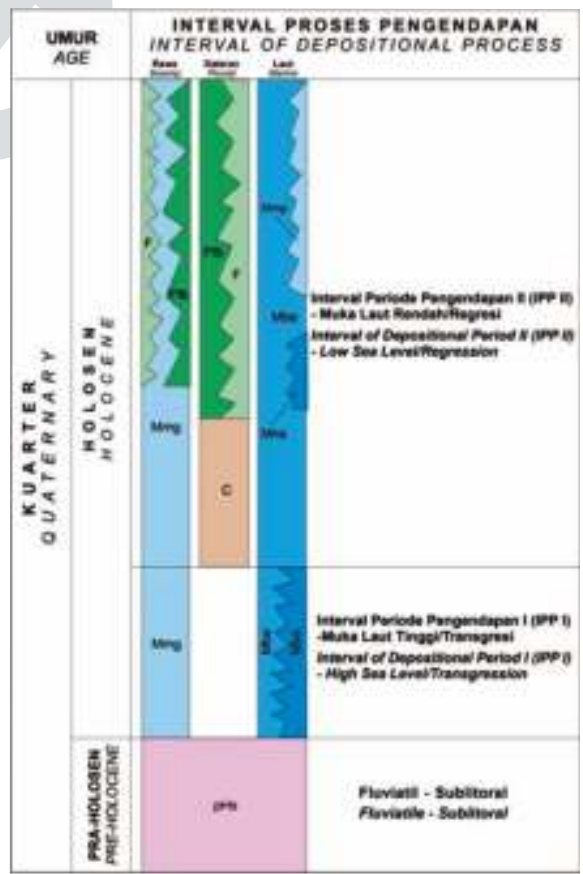

Gambar 11. Kolom interval periode pengendapan periode Holosen di daerah penelitian. 
Analisis pentarikhan radiokarbon dilakukan pada sampel dengan kode NB 025 yang diambil di endapan rawa, endapan limpah banjir dan endapan pantai di daerah Yaro yang terletak di sebelah barat daerah penelitian. Dari analisis umur, terdapat 6 umur dengan paling muda berumur $3.790 \pm 130$ pada endapan limpah banjir dan paling tua berumur $11.890 \pm 220$ pada endapan pantai (Gambar 12). Batas antara interval periode pengendapan 1 dan 2 menurut analisis pentarikhan radiokarbon terjadi di antara kisaran 9.200 -10.700 tahun yang lalu.

Proses sedimentasi daerah penelitian ditandai dengan terbentuknya sedimen klastika dipengaruhi oleh banyak faktor seperti proses fisika, pasokan material, iklim, tektonik, dan muka airlaut (Elliot, 1986). Proses arus pasang-surut dan gelombang sebagai proses fisika sangat mempengaruhi perkembangan lingkungan di cekungan Kuarter Nabire yang menghasilkan endapanendapan Kuarter yang tidak terkonsolidasi dengan baik. Hal tersebut terbukti dari perubahan susunan material yang berubah secara cepat dan tidak teratur.

Perkiraan kecepatan pengangkatan dan kedalaman air (paleowater depth) saling berkaitan satu dengan yang lainnya (Chappel dan Shackleton, 1986). Chappel dan Polach (1991) melakukan penelitian di Huon Peninsula, Papua Nugini dan disimpulkan bahwa pada umumnya posisi terumbu karang terletak pada kedalaman 2-5 m di bawah laut. Posisi fasies terumbu karang pada saat ini adalah $0 \mathrm{~m}$ yang berarti relatif sama dengan permukaan laut kini. Mereka juga menyatakan bahwa kondisi tersebut terjadi pada saat situasi muka airlaut naik setelah peng-esan (post-glacial sea level rise). Sekiranya hal tersebut benar, maka pengangkatan yang berlangsung di daerah timur Indonesia berkisar antara 0,1-0,25 mm/tahun. Hal ini dapat terlihat di beberapa daerah penelitian seperti Kalisemen yang mengindikasikan adanya pengaruh tektonik ketika muka airlaut tinggi dan mengalami pengangkatan (base level naik). Efek tektonik di kawasan dekat pantai hingga pantai sangat dipengaruhi oleh bentuk dan ukuran cekungan serta kedalaman air laut. Ketidakteraturan dari distribusi fasies pantai di daerah penelitian disebabkan oleh bergeraknya dasar cekungan.

Thomas et al. (2007) dalam studi mereka terhadap aspek fluvial yang berkaitan dengan perubahan klim akhir Kuarter di timurlaut Queensland, Australia,

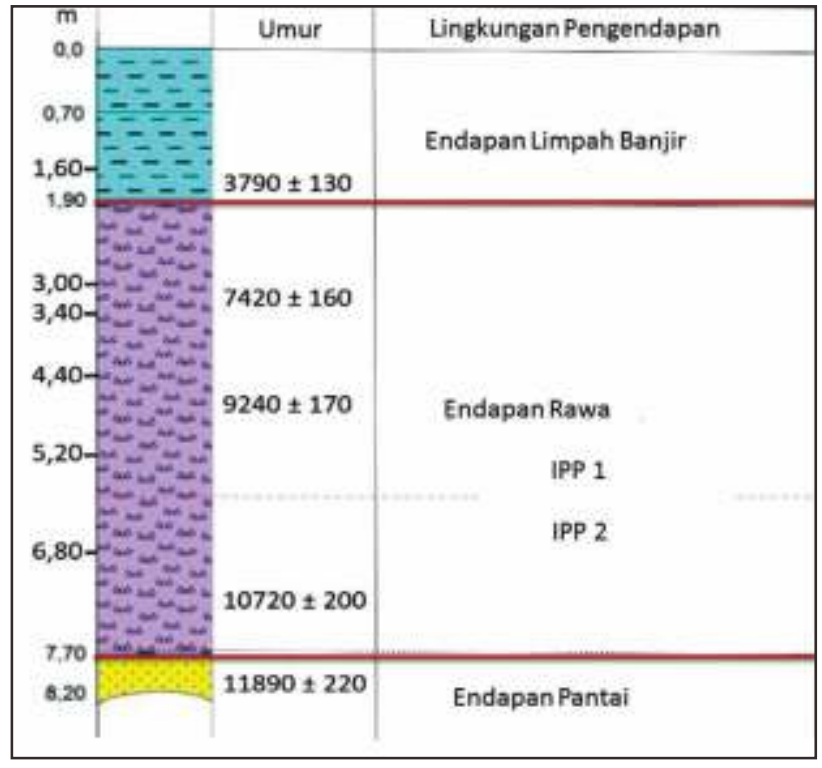

Gambar 12. Kolom analisis pentarikhan radiokarbon pada sampel NB 025 di daerah Yaro yang terletak di sebelah barat.

menyatakan bahwa kipas aluvial yang terbentuk sejak 14.000 tahun yang lalu terpotong oleh sedimen Holosen dengan kemiringan yang curam karena daerahnya tidak stabil pada 12.000 tahun yang lalu dan juga terkait dengan perubahan iklim. Mereka berasumsi proses tersebut sangat berkaitan dengan ikim Australia-Asia yang berakibat beralihnya sistem fluvial. Bowen (1978) berasumsi bahwa posisi muka airlaut pada 17.000 tahun yang lalu di Australia berubah dari -130 m menjadi 180 m, sedangkan di Amerika dari -90 menjadi $130 \mathrm{~m}$. Naiknya muka airlaut di belahan bumi selatan dan utara kemungkin berlangsung secara global dengan kecepatan berbeda dari suatu tempat ke tempat lainnya karena faktor tektonik. Peristiwa global tersebut kemungkinan besar berhubungan dengan mulainya es mencair saat interglasiasi. Perbedaan suhu antara maksimum glasiasi yang terjadi pada 18.000 tahun yang lalu dan permulaan Holosen sebagai iklim optimum atau sebagai puncak dari interglasiasi pada 9.000 tahun yang lalu yang berkaitan dengan sirkulasi iklim ketika itu (Williams et al., 1993). Penelitian stratigrafi rinci dan penentuan umum terumbu Holosen telah membuktikan bahwa muka airlaut tinggi terjadi pada 9.000-10.000 tahun yang lalu (Chappel dan Polach, 1991). Panrinath et al. (2001) mempelajari perubahan muka airlaut dan sedimentasi pada data bor periode Kuarter akhir menyatakan bahwa umur kayu dan gambut hasil pentarikhan radiokarbon adalah antara 
10.760 - 9.280 tahun yang lalu. Berdasarkan analisis pentarikhan radiokarbon di daerah penelitian, batas antara interval 1 dan interval 2 terjadi sekitar 9.240 10.720 tahun yang lalu. Hal ini berarti bahwa interval 1 cenderung terbentuk sebelum 10.000 tahun yang lalu. Apabila dugaan ini benar, maka terbentuknya sedimen Holosen di daerah ini lebih cepat akibat faktor penurunan yang berpengaruh ketika itu, ditambah daerah itu merupakan wilayah pesisir.

Perlmutter dan Matthews (1989) menyebutkan bahwa sirkulasi iklim dapat di pantai dari rangkaian fasies proses sedimentasi dari meluas atau menyusutnya lingkungan pengendapan khususnya sistem fluvial. Blum dan Valastro (1989) mengemukakan bahwa morfologi sistem fluvial berhubungan dengan evolusi alur aliran sungai dan keseimbangan morfologi di akhir Holosen yang dicirikan oleh hubungan antara faktor tidak terhentinya pengendapan serta pasokan material yang mengikuti siklus iklim. Proses demikian identik dengan ketergantungan proses pengendapan fluvial di daerah penelitian yang dikontrol oleh siklus berubahnya iklim. Kemunculan fluvial pada periode II di daerah penelitian khususnya Yaromakmur diakibatkan oleh turunnya muka air laut yang semakin berkurang dimensi fluvialnya. Kondisi ini menunjukkan kecenderungan tingkat energi semakin mengecil berkaitan dengan jumlah volume air ketika itu. Jumlah volume air tersebut berhubungan dengan tingkat kelembaban yang bergantung pada siklus perubahan iklim. Pada fasies endapan rawa bakau yang dicirikan dengan keterdapatan Rhizophora sp., Sonneratia alba, dan Bruguiera cylindrica, terjadi penipisan endapan gambut dan pola warna dari atas ke bawah dimulai dari atas terang lalu agak gelap kemudian gelap dan kembali menjadi agak gelap pada fasies tersebut. Peristiwaperistiwa tersebut menunjukan indikasi bahwa iklim menuju ke arah kekeringan.

\section{KESIMPULAN}

Perubahan fasies pengendapan dari rangkaian stratigrafi, baik secara vertikal dan horizontal, tidak teratur dan tidak homogen dari waktu ke waktu. Hal ini dikarenakan adanya gaya endogen dasar cekungan yang bergerak naik turun. Naik turunnya dasar alas cekungan (base level) semata-mata diakibatkan oleh tektonik.

Turun-naiknya muka airlaut di daerah penelitian cenderung tidak mengikuti perubahan global. Hal ini dibuktikan dengan adanya naik turun muka airlaut secara lokal. Oleh karena itu, perubahan muka airlaut global dikendalikan oleh tektonik.

Perubahan iklim terekam pada susunan fasies darat yang dibuktikan dengan meluas dan menyusutnya lingkungan rawa sebagai indikator berubahnya iklim mengikuti tingkat kebasahan atau kelembaban. Selain itu, menyusut dan meluasnya sistem endapan fluvial adalah bukti berubahnya energi aliran akibat iklim berubah mengikuti tingkat kelembaban. Sejak terbentuknya interval periode 2 (dua) hingga sekarang menunjukkan bahwa iklim ketika itu menuju minimum, yaitu kering.

\section{UCAPAN TERIMAKASIH}

Terimakasih kepada Kepala Pusat Survei Geologi beserta jajaran manajemen sehingga tulisan ini dapat terwujud. Ucapan terimakasih juga penulis sampaikan kepada seluruh anggota tim Pemetaan Geologi Kuarter Lembar Karadiri skala 1 : 50.000 tahun 2017 (Rohman, Darwin, Subiyanto, Malik dan Dadang) atas tenaga, waktu dan pemikirannya dalam proses persiapan hingga penyelengaraan penelitian ini. Terimakasih juga penulis ucapakan kepada bapak Sigit Maryanto atas arahan, diskusi dan bimbingan penulisan, demi lebih baiknya tulisan ini.

\section{ACUAN}

Allen, P.A. and Allen, J.R., 1990. Basin Analysis Principles and Application. Blackwell Scientific Publication, 451 h.

Bachri, S., 2014. Kontrol Tektonik dan Struktur Geologi Terhadap Keterdapatan Hidrokarbon di daerah Papua, Jurnal Geologi dan Sumberdaya Mineral, 15(3): 133-141.

Bemmelen, R.W. Van, 1949. The Geology of Indonesia. Martinus Nyhoff, The Haque, Nederland.

Blum, M.D. and Valastro, S., Jr., 1989. Response of the Pedernales River of Central Texas to Late Holocene Climatic Change. Association of American Geographer.

Bowen, D.Q., 1978. Quaternary Geologi: A Stratigraphic Framework for Multidisciplinary Work. Pergamon Press: $221 \mathrm{~h}$.

Chappel, J. and Polach., 1991. Post Glacial Sea Level Rise from a Coral Record at Huon Peninsula, Papua New Guinea. Nature, 349: 147-149 
Chappel, J. and Shackleton, N.J., 1986. Oxygen Isotopes Sea Level. Nature, 324: 137-140

Elliot, T., 1986, Siliciclastic Shorelines. In: Reading H.G. (ed.), Sedimentary Environments and Facies. Blackwell Scientific Publications, Second Edition, p. 155-188

Harahap, B.H., Hakim, A.S. dan Dow, D.B., 1990. Peta Geologi Lembar Enarotali, Irian Jaya Skala 1 : 250.000. Pusat Penelitian dan Pengembangan Geologi, Bandung

Kondolf, M. and Piegay, H, 2016. Tools in Fluvial Geomorphology, Second Edition. John Wiley \& Sons, Chicester, UK.

Miall, A.D.,1992. Alluvial Deposits. In: Walker R.G. James, N.P. (eds.), Facies Models Response to Sea Level Change. Geological Association of Canada: 119-142.

Parinath, K., Shankar, R. and Yadava, M.G., 2001. Late Quaternary Changes in Sea Level Sedimentation Rate Along the Southwestern Coast of India: Evidence from Radiocarbon Dates. Current Science, 81( 5):594-600.

Perlmutter, M.A. and Matthews, M.A., 1989. Global Cyclostratigraphy. In : T.A. Cross (ed.), Quantitative Dynamic Stratigraphy. Pretice Englewood, New Jersey: 233-260.

Thomas, M.F., Nott, J., Murray, A.S. and Price, D.M., 2007. Fluvial Response to Late Quaternary Climate Change in NEQueensland, Australia. Paleography, Palaeoclimatology, Palaeoecology, 251: 119-136.

Walker, R.G. and James. N.P., 1992. Preface. In: Miall, A.D. and Jones, N.P. (eds), Facies Models Response to Sea Level Change. Geological Assocoation of Canada.

Williams, M.A.J., Dunkerley, D.L., De Decker, P., Kershaw, A.P. and Stokes, T.J., 1993. Quaternary Environments. Edward Arnold, A division of hodder \& Stoughton, London New York Melbourne Auckl:329 pp. 